\title{
Nucleoplasmic calcium signaling and cell proliferation: calcium signaling in the nucleus
}

\author{
Rodrigo R Resende, Lidia M Andrade ${ }^{2}$, Andre G Oliveira ${ }^{3}$, Erika S Guimarães ${ }^{3}$, Silvia Guatimosim³ \\ and M Fatima Leite $3,4,5^{*}$
}

\begin{abstract}
Calcium $\left(\mathrm{Ca}^{2+}\right)$ is an essential signal transduction element involved in the regulation of several cellular activities and it is required at various key stages of the cell cycle. Intracellular $\mathrm{Ca}^{2+}$ is crucial for the orderly cell cycle progression and plays a vital role in the regulation of cell proliferation. Recently, it was demonstrated by in vitro and in vivo studies that nucleoplasmic $\mathrm{Ca}^{2+}$ regulates cell growth. Even though the mechanism by which nuclear $\mathrm{Ca}^{2+}$ regulates cell proliferation is not completely understood, there are reports demonstrating that activation of tyrosine kinase receptors (RTKs) leads to translocation of RTKs to the nucleus to generate localized nuclear $\mathrm{Ca}^{2+}$ signaling which are believed to modulate cell proliferation. Moreover, nuclear $\mathrm{Ca}^{2+}$ regulates the expression of genes involved in cell growth. This review will describe the nuclear $\mathrm{Ca}^{2+}$ signaling machinery and its role in cell proliferation. Additionally, the potential role of nuclear $\mathrm{Ca}^{2+}$ as a target in cancer therapy will be discussed.
\end{abstract}

Keywords: Nucleoplasmic reticulum, Nuclear calcium channels, Nuclear calcium, Cell proliferation

\section{Introduction}

Intracellular calcium $\left(\mathrm{Ca}^{2+}\right)$ participates as a second messenger in several signaling pathways coordinating key events in a variety of cellular functions [1]. $\mathrm{Ca}^{2+}$ Signals are generally initiated by the binding of a hormone or growth factor to a transmembrane receptor, most commonly G protein coupled receptor (GPR) or tyrosine kinase receptor (RTK). The activation of such receptors recruits several second messengers, including phospholipase C (PLC) that, once activated, cleaves phosphatidylinositol 4,5-biphosphate $\left(\mathrm{PIP}_{2}\right)$ producing diacylglycerol and inositol-1,4,5-trisphosphate $\left(\operatorname{InsP}_{3}\right)$. $\mathrm{InsP}_{3}$ then binds to the $\mathrm{InsP}_{3}$ receptor $\left(\mathrm{InsP}_{3} \mathrm{R}\right)$, activating its channel to release $\mathrm{Ca}^{2+}$ from the endoplasmic reticulum. Once in the cytosol, $\mathrm{Ca}^{2+}$ can participate in several intracellular cascades and activate another class of $\mathrm{Ca}^{2+}$ channels, the ryanodine receptor (RyR), triggering a process denoted $\mathrm{Ca}^{2+}$-induced $\mathrm{Ca}^{2+}$ release [1]. The type II and III RyR are also sensitive to cyclic ADP-ribose (cADPR) [2,3], a process first demonstrated in sea urchin

\footnotetext{
* Correspondence: leitemd@dedalus.lcc.ufmg.br

${ }^{3}$ Physiology and Biophysics, Federal University of Minas Gerais, Belo Horizonte, MG, Brazil

${ }^{4}$ Howard Hughes Medical Institute, Chevy Chase, Maryland, MD, USA Full list of author information is available at the end of the article
}

eggs [4], but now known to mobilize $\mathrm{Ca}^{2+}$ in a wide range of mammalian cell types [3,5-8]. Members of a third family of intracellular $\mathrm{Ca}^{2+}$ channels, the two pore channels (TPCs), are activated by nicotinic acid adenine dinucleotide phosphate (NAAD) which promotes release of $\mathrm{Ca}^{2+}$ from acidic organelles $[9,10]$. Like cADPR, NAADP was discovered in sea urchin eggs [11] and has now been found to induce $\mathrm{Ca}^{2+}$ signaling in mammalian cells as well $[9,10]$. Interactions among these different intracellular $\mathrm{Ca}^{2+}$ channels coordinate cellular responses mediated by $\mathrm{Ca}^{2+}$, both in health and disease. However little is known regarding the interaction of intracellular $\mathrm{Ca}^{2+}$ channels in the regulation of nuclear $\mathrm{Ca}^{2+}$ signaling.

One way by which intracellular $\mathrm{Ca}^{2+}$ regulates multiple cell functions is through spatial segregation of $\mathrm{Ca}^{2+}$ signaling. Indeed, subcellular increases in $\mathrm{Ca}^{2+}$ modulate not only physiological but also pathological events. For example, the physiological secretion of zymogen granules in pancreatic acinar cells is triggered by a localized sub-apical $\mathrm{Ca}^{2+}$ increase that does not spread throughout the entire cell [12]. In the other hand, the hypertrophic response in cardiomyocytes depends mostly on nuclear $\mathrm{Ca}^{2+}$ signals [13]. Additional examples of cellular processes modulated by subcellular $\mathrm{Ca}^{2+}$ signaling include the extension of growth cones in neuronal 
cells $[14,15]$ and the establishment of specific gene transcription signatures [16], regulating development and differentiation [17-20], among others [21].

Moreover, the presence of another regulatory nuclear $\mathrm{Ca}^{2+}$ domain, denoted the nucleoplasmic reticulum $[22,23]$ was reported in a wide variety of cells, from plants to animals (reviewed in [24]). The nucleoplasmic reticulum, of which 2 classes have been described, is a reticular membrane network of $\mathrm{Ca}^{2+}$ stores that is continuous with the endoplasmic reticulum and the nuclear envelope. The type I contains invaginations of the inner membrane of the nuclear envelope, and the type II contains both the inner and outer nuclear envelope membrane. These two classes of the nucleoplasmic reticulum can coexist within the same nucleus (reviewed in [24]), and their structure undergoes dynamic remodeling [25]. With the capacity to regulate $\mathrm{Ca}^{2+}$ signals in subnuclear regions, the presence of such machinery might provide a potential mechanism by which nucleoplasmic $\mathrm{Ca}^{2+}$ could simultaneously regulate many independent processes in the nucleus.

Although it is well known that nuclear $\mathrm{Ca}^{2+}$ has biological effects that differ from those mediated by increases in cytosolic $\mathrm{Ca}^{2+}[21]$, the mechanisms by which $\mathrm{Ca}^{2+}$ is specifically increased in the nucleoplasm are a topic of debate. It was initially proposed that nuclear $\mathrm{Ca}^{2+}$ signaling would occur by passive diffusion of cytosolic $\mathrm{Ca}^{2+}$ across the nuclear envelope into the nucleoplasm. However, as it will be discussed in more detail, the nuclear interior has all the machinery required to produce localized $\mathrm{Ca}^{2+}$ signals, supporting the concept of the nuclear compartment as an independent apparatus to trigger $\mathrm{Ca}^{2+}$ signals. Moreover, the mechanisms and pathways by which localized $\mathrm{Ca}^{2+}$ signals in the nucleus regulate cell growth have only recently been investigated. The emerging model (Figure 1) shows that upon growth factor stimulation, RTKs translocate to the nucleus to induce hydrolysis of nuclear PIP2, generating InsP3 in the nucleoplasm, which leads to nuclear $\mathrm{Ca}^{2+}$ signals that can control cell growth [26-28] (Figure 1). This review highlights recent advances on nuclear $\mathrm{Ca}^{2+}$ signaling and its role in cell proliferation.

\section{$\mathrm{Ca}^{2+}$ signaling in the nucleus}

The nucleus is separated from the cytosol by the nuclear envelope, which is a specialized region of the endoplasmic reticulum, comprised of phospholipid bilayers [24]. However, the nuclear envelope contains pores that are permeable to molecules up to $60 \mathrm{kDa}$ in size [29]. In the absence of a gating mechanism, a pore of this size would allow rapid equilibration of $\mathrm{Ca}^{2+}$ between the nucleus and cytosol. Indeed, under certain circumstances, free diffusion of $\mathrm{Ca}^{2+}$ through the nuclear pore occurs [30]. For example, stimulation of basophilic leukemia cells with antigen or photoreleased $\mathrm{InsP}_{3}$ triggered $\mathrm{Ca}^{2+}$ waves that spread from the cytosol into the nucleus [31]. Similar observations have been made in hepatocytes stimulated with vasopressin [32]. In contrast, several reports have demonstrate the existence of a nuclearcytosolic $\mathrm{Ca}^{2+}$ gradient in a number of cell types [33,34], indicating that the permeability of nuclear pores to this ion can be regulated. However, the detection of such gradient can be incorrectly inferred depending on the technique used to measure intracellular $\mathrm{Ca}^{2+}$ in different compartments. Some of the commonly used organic $\mathrm{Ca}^{2+}$ indicators can display uneven distribution in the interior of the cells and can preferentially accumulate in membrane compartments such as the ER and the nucleoplasm. More importantly, the affinity of fluorescent probes for $\mathrm{Ca}^{2+}$ can vary depending on the cellular environment (reviewed [35]). Although each method for analyzing $\mathrm{Ca}^{2+}$ has certain drawbacks it is now appreciated that $\mathrm{Ca}^{2+}$ signaling is regulated at the subcellular level, and that this level of regulation is necessary for $\mathrm{Ca}^{2+}$ to act as a second messenger that regulates multiple cell functions simultaneously.

The nuclear envelope itself is a $\mathrm{Ca}^{2+}$ rich compartment, accumulating $\mathrm{Ca}^{2+}$ via a $\mathrm{Ca}^{2+}$-ATPase pump (SERCA) and a $\mathrm{Na}^{+} / \mathrm{Ca}^{2+}$-exchanger [36-38] and releasing it via channels that are sensitive to $\operatorname{InsP}_{3}[37,39]$, cADPR [39,40], and NAADP [41]. The $\mathrm{Ca}^{2+}$-ATPase pump was shown to be present only in the outer membrane of the nuclear envelop, while the $\mathrm{Na}^{+} / \mathrm{Ca}^{2+}$-exchanger, is expressed in the inner membrane [38,42]. Regarding the intracellular $\mathrm{Ca}^{2+}$ channels, the RyRs appears to be present on both leaflets of the nuclear envelope [43]. Similarly, there are reports of $\operatorname{InsP}_{3} R s$ in the inner and outer membrane $[28,44,45]$. In addition, it was shown that ADP-ribosyl (CD38), an enzyme required for generation of cADPR, is located on the inner membrane of the nuclear envelope [40]. In Aplysia neurons, depolarization is the signal that triggers the translocation of CD38 to the nucleus [46]. Moreover, the nuclear envelope possess the tool kit necessary to produce $\operatorname{InsP}_{3}$, including PIP2, and PLC [47], and this machinery may be activated selectively through tyrosine kinase pathway [48].

However, the nuclear envelope is not the only nuclear site containing the $\mathrm{Ca}^{2+}$ signaling machinery. The nucleoplasmic reticulum represents another specialized cellular compartment involved in regulation in time and space of specific intracellular $\mathrm{Ca}^{2+}$ signaling events. For instance, both the Ins $\mathrm{P}_{3} \mathrm{R}$ and the $\mathrm{RyR}$ are found in the nucleoplasmic reticulum [22,23]. Importantly, the $\mathrm{InsP}_{3}$-Kinase (IP3KB), the isoform that inactivates the $\mathrm{InsP}_{3}$ by phosphorylating it, was also reported to be located in the nucleoplasmic reticulum, where it may function to terminate the $\operatorname{Ins}_{3}$ mediated $\mathrm{Ca}^{2+}$ signal [49]. In addition, SERCA was also 


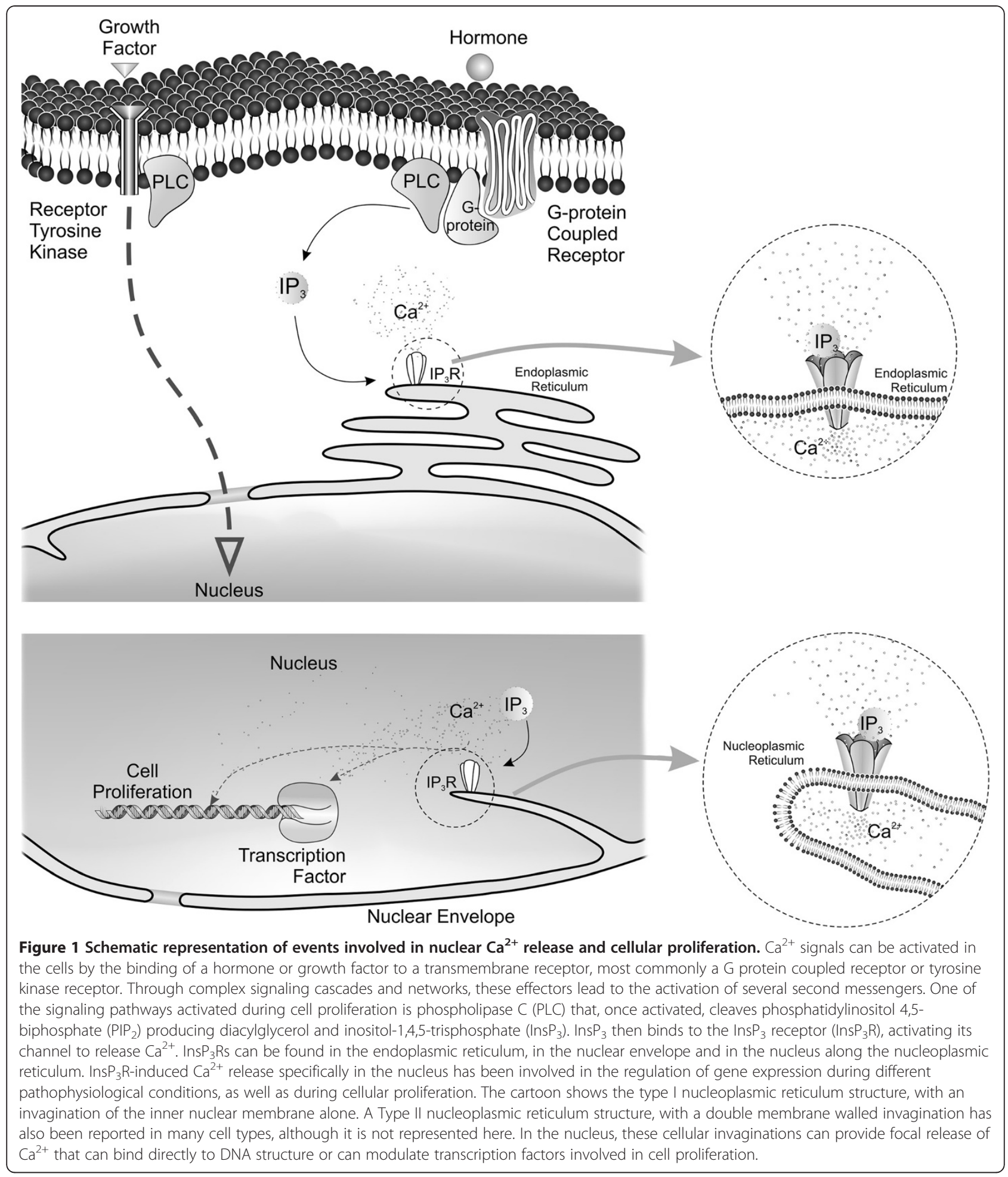

shown to be expressed along invaginations of the nucleoplasmic reticulum [50]. Therefore, there are several reports describing an active $\mathrm{Ca}^{2+}$ signaling regulatory domain deep in the nucleus, along the nucleoplasmic reticulum, providing further spatial control of $\mathrm{Ca}^{2+}$ within this cellular compartment $[22,51,52]$.
Corroborating these findings, there is a growing body of data demonstrating that the nucleus has the capacity to independently generate $\mathrm{Ca}^{2+}$ signals. Several in vitro studies have shown that $\mathrm{InsP}_{3}$ releases $\mathrm{Ca}^{2+}$ directly from the nuclear envelop into the nucleus [33,39,44,53,54]. Accordingly, it has been demonstrated in a liver cell line that extracellular 
ATP can activate nuclear $\mathrm{Ca}^{2+}$ release, via an $\mathrm{InsP}_{3}-$ dependent mechanism [55]. In cardiomyocytes, endothelin1 has also been shown to elicit a local nuclear envelope $\mathrm{Ca}^{2+}$ release via $\mathrm{Ins}_{3} \mathrm{R}$ that activates nuclear CaMKII triggering HDAC5 phosphorylation and its nuclear export [56]. This signaling pathway has been implicated in the regulation of gene transcription in adult ventricular myocytes in response to neurohumoral signals during hypertrophy. Similar to InsP $P_{3}$, cADPR can also increase $\mathrm{Ca}^{2+}$ in isolated cell nuclei $[33,39,40]$.

One of the proposed mechanism by which Ins $_{3}$ generates nuclear $\mathrm{Ca}^{2+}$ signaling is via translocation of activated RTKs from the plasma membrane to the nuclear interior. For instance, it was shown that IGF-1 and integrins caused PIP2 breakdown in the nucleus but not at the plasma membrane [48]. Similarly, activation of the hepatocyte growth factor (HGF) receptor c-Met in a liver cell line and insulin receptor in primary hepatocytes caused PIP2 breakdown in the nucleus resulting in $\mathrm{InsP}_{3}$ formation that was followed by nuclear $\mathrm{Ca}^{2+}$ signals [26,27] (Figure 1). The triggering of this highly localized cascade was dependent on the rapid translocation of the activated HGF receptor to the nucleus, through a mechanism that depends on the adaptor protein Gab-1 and importin-B [26]. Moreover, it also has been hypothesized that relocation of MAP kinase to the nucleus activates nuclear phospholipase $\mathrm{C}$ to generate $\mathrm{InsP}_{3}$ there [43].

Once in the nucleus, $\mathrm{Ca}^{2+}$ signals directly regulate signaling pathways distinct from those mediated by cytosolic $\mathrm{Ca}^{2+}$, for instance they stimulate the intranuclear activity of PKC [22] and CaMK-IV [57]. Nuclear $\mathrm{Ca}^{2+}$ also plays a significant role in regulating the transcription factor CREbinding protein and its coactivator, CREB-binding protein (CBP) [58]. Transcriptional activation of Elk-1 by EGF was also shown to depend on nuclear rather than cytosolic $\mathrm{Ca}^{2+}$ [59]. On the other hand, nuclear $\mathrm{Ca}^{2+}$ can negatively regulate the activity of transcription factors, such as TEAD [60]. Moreover, nuclear $\mathrm{Ca}^{2+}$ has also been implicated in modulating cardiac hypertrophy [13,51] and within the nucleus $\mathrm{Ca}^{2+}$ was shown to bind to and directly regulate DNA structure [61]. Another evidence of the role of nuclear $\mathrm{Ca}^{2+}$ signaling pathway came from studies showing that in skeletal muscle cell, two-photon photorelease of caged $\mathrm{Ca}^{2+}$ near the nucleoplasmic reticulum was found to elicit a $\mathrm{Ca}^{2+}$-induced $\mathrm{Ca}^{2+}$ release event within the nucleus [23]. More recently, it was demonstrated that nuclear rather than cytosolic $\mathrm{Ca}^{2+}$ signals specifically control the progression through early prophase, showing that nucleoplasmic $\mathrm{Ca}^{2+}$ regulates cell proliferation [62].

\section{Nuclear $\mathrm{Ca}^{2+}$ and cell proliferation}

It has been long recognized that $\mathrm{Ca}^{2+}$ signals have an important role throughout the mammalian cell cycle and are especially important in early $G_{1}$ and $G_{1} / S$ and $G_{2} / M$ transitions [63], with the first major $\mathrm{Ca}^{2+}$ transient occurring just prior to entry into mitosis, and the second one occurring during the metaphase-anaphase transition $[63,64]$. Indeed, $\mathrm{Ca}^{2+}$ is the most prominent messenger required through these cycle points $[65,66]$ and downstream targets of $\mathrm{Ca}^{2+}$ have also been implicated in cell cycle progression as well $[67,68]$.

Heterologous expression of the $\mathrm{Ca}^{2+}$ binding protein parvalbumin has been used to study the role of $\mathrm{Ca}^{2+}$ signals in the regulation of the cell cycle. This protein is normally expressed in skeletal muscle and neurons [69], and is known to buffer $\mathrm{Ca}^{2+}$ [70]. The first report using parvalbumin as a molecular tool to buffer intracellular $\mathrm{Ca}^{2+}$ and study cellular growth, showed that reducing $\mathrm{Ca}^{2+}$ slowed progression through the cell cycle [68]. However, it is now known that the effects of $\mathrm{Ca}^{2+}$ on proliferation correlate with the subcellular compartment where $\mathrm{Ca}^{2+}$ is released. Using parvalbumin variants, selectively targeted to distinct intracellular $\mathrm{Ca}^{2+}$ rich compartments, it was found that buffering mitochondrial $\mathrm{Ca}^{2+}$ inhibits apoptosis and accelerates hepatocyte proliferation [71]. In contrast, buffering cytosolic $\mathrm{Ca}^{2+}$ was shown to retard liver regeneration and progression through the cell cycle after partial hepatectomy [72]. Since cytosolic $\mathrm{Ca}^{2+}$ can increase through a number of mechanisms, it is believed that, in this compartment, $\mathrm{Ca}^{2+}$ may have different effects on cell growth $[71,73,74]$. On the other hand, it was shown that nucleoplasmic rather than cytosolic $\mathrm{Ca}^{2+}$ is essential for liver cell line proliferation, and is necessary in particular for progression through early prophase [62]. It was also found that liver tumors implanted in nude mice grew much more slowly when expressing parvalbumin in their nuclei compared to the cytosol [62]. Moreover, HGF and insulin, two potent growth factors in liver, that induce cell proliferation during liver regeneration, were shown to selectively form $\mathrm{InsP}_{3}$ in the nucleus to initiate nuclear $\mathrm{Ca}^{2+}$ signals [22,27] (Figure 1). Since the nucleoplasmic reticulum is known to be abundant in many tumor cell types [24], one would expect that the existence of these nuclear invaginations could provide further specificity to cell proliferation by allowing the focal delivery of $\mathrm{Ca}^{2+}$ to particular sites within the nucleus.

Although, the proteins that link nuclear $\mathrm{Ca}^{2+}$ signals to cell proliferation have not been clearly identified, more recent findings in liver tumor cells indicated the endopeptidase legumain (LGMN) as a novel target of nuclear $\mathrm{Ca}^{2+}$ [75]. Using Rapid Subtraction Hybridization ( $\mathrm{RaSH}$ ) to subtract genes in liver cells expressing the $\mathrm{Ca}^{2+}$ buffer protein parvalbumin targeted to the nucleus, from genes in cells expressing a mutated form of nuclear-targeted parvalbumin which has one of the two $\mathrm{Ca}^{2+}$-binding sites inactivated. The authors identified thirteen genes whose expression was affected by a small alteration in nuclear $\mathrm{Ca}^{2+}$ concentration. 
LGMN was one of such genes and upon further validation was demonstrated to be regulated by nuclear $\mathrm{Ca}^{2+}$ signals at the transcriptional level. LGMN was first recognized in plants [76] and later in humans and mice [77]. It is present in the tumor microenvironment where it is expressed by macrophages and contributes to metastatic behavior by promoting cell migration and tissue invasion. It is known that increased expression of LGMN is associated with poor tumor differentiation [78]. For instance, it was demonstrated that LGMN co-localizes with integrins at the invading front of tumors and expression of this enzyme was shown to be associated with increased invasiveness $[78,79]$. So, it was shown that when $\mathrm{Ca}^{2+}$ was buffered in the nucleus of the cells, LGMN expression decreased, impairing cell proliferation [75]. Additionally, this work also provided evidence that nuclear $\mathrm{Ca}^{2+}$ signals regulate cell proliferation at least in part through the modulation of gene expression (Figure 1). Other targets for nuclear $\mathrm{Ca}^{2+}$ that are involved in cell proliferation still remain to be described.

Altered nuclear morphology is a common feature of many cancers [24] and it has been proposed that information regarding the nucleoplasmic reticulum invaginations could be used in combination with other nuclear anomalies as markers of malignancy [80]. More recently, it was also proposed that nuclear $\mathrm{Ca}^{2+}$ buffering could be used in conjunction with radiotherapy as a therapeutic potential for the treatment of carcinoma. Ionizing radiation concomitant with nuclear $\mathrm{Ca}^{2+}$ buffering showed superior outcome, compared to irradiation alone [81]. Corroborating previous findings, the beneficial effect of nuclear $\mathrm{Ca}^{2+}$ buffering in the proposed antitumor therapy was shown to be due to changes caused in expression level of genes involved in the regulation of cell proliferation [59]. Moreover, it was also shown that buffering nuclear $\mathrm{Ca}^{2+}$ reduced the rate of tumor cell proliferation, without affecting cells from normal tissue [81], suggesting higher selectivity of nuclear $\mathrm{Ca}^{2+}$ towards controlling cancer cell growth. Further studies are required to determine the mechanistic basis for the differential sensitivity of normal versus cancer cell proliferation to changes in nuclear $\mathrm{Ca}^{2+}$. Nonetheless, these findings suggest that buffering nuclear $\mathrm{Ca}^{2+}$ could be one strategy employed to inhibit the growth of tumors without affecting normal tissue, either alone or in association therapy.

\section{Conclusions}

$\mathrm{Ca}^{2+}$ is important to several signaling pathways among virtually every cell type. The central mechanism by which $\mathrm{Ca}^{2+}$ regulates protein functions depends on how and where it is released into the cell. The role of nuclear $\mathrm{Ca}^{2+}$ in cell proliferation was demonstrated in vitro by showing that nuclear $\mathrm{Ca}^{2+}$ buffering reduced proliferation rate through blocking cell cycle in $\mathrm{G}_{2} / \mathrm{M}$ phase. It was also demonstrated that nuclear $\mathrm{Ca}^{2+}$ plays a role on tumor growth in vivo and it can alter the expression of genes involved in cell proliferation. Moreover, modulation of nuclear $\mathrm{Ca}^{2+}$ signaling was shown to be a potential target to treat cancer. However further studies are needed to better understand how nuclear $\mathrm{Ca}^{2+}$ can be generated and how it regulates cell proliferation and cell cycle progression. These findings would have strong potential as therapeutic targets in degenerative diseases or cancer.

\section{Competing interests}

The authors declare that they have no competing interests.

\section{Authors' contributions}

All authors contributed in the conception and writing of the manuscript. All authors edited and approved the final version.

\section{Acknowledgements}

We thank Howard Hughes Medical Institute (HHMI), Conselho Nacional de Desenvolvimento Científico e Tecnológico (CNPq), Fundação de Amparo à Pesquisa do Estado de Minas Gerais (FAPEMIG), PRONEX and Coordenação de Aperfeiçoamento de Pessoal de Nível Superior (CAPES).

\section{Author details}

${ }^{1}$ Department of Biochemistry and Immunology, Federal University of Minas Gerais, Belo Horizonte, MG, Brazil. ²René Rachou Research Center, Oswaldo Cruz Foundation, Belo Horizonte, MG, Brazil. ${ }^{3}$ Physiology and Biophysics, Federal University of Minas Gerais, Belo Horizonte, MG, Brazil. ${ }^{4}$ Howard Hughes Medical Institute, Chevy Chase, Maryland, MD, USA. ${ }^{5}$ Institute of Biological Sciences Bloco A4 246, Federal University of Minas Gerais, Av Antônio Carlos, 6627, 30370-920, Belo Horizonte, Brazil.

Received: 5 May 2011 Accepted: 12 February 2013

Published: 21 February 2013

\section{References}

1. Berridge MJ, Bootman MD, Roderick HL: Calcium signalling: dynamics, homeostasis and remodelling. Nat Rev Mol Cell Biol 2003, 4:517-529.

2. Sonnleitner A, Conti A, Bertocchini F, Schindler H, Sorrentino V: Functional properties of the ryanodine receptor type 3 (RyR3) Ca2+ release channel. EMBO J 1998, 17:2790-2798.

3. Meszaros LG, Bak J, Chu A: Cyclic ADP-ribose as an endogenous regulator of the non-skeletal type ryanodine receptor Ca2+ channel. Nature 1993, 364:76-79.

4. Galione A, Lee HC, Busa WB: $\mathrm{Ca}(2+)$-induced $\mathrm{Ca} 2+$ release in sea urchin egg homogenates: modulation by cyclic ADP-ribose. Science 1991, 253:1143-1146.

5. Cancela JM, Petersen $\mathrm{OH}$ : The cyclic ADP ribose antagonist 8-NH2-cADPribose blocks cholecystokinin-evoked cytosolic Ca2+ spiking in pancreatic acinar cells. Pflugers Arch 1998, 435:746-748.

6. Kuemmerle JF, Makhlouf GM: Agonist-stimulated cyclic ADP ribose. Endogenous modulator of $\mathrm{Ca}(2+)$-induced $\mathrm{Ca} 2+$ release in intestinal longitudinal muscle. J Biol Chem 1995, 270:25488-25494.

7. Clementi E, Riccio M, Sciorati C, Nistico G, Meldolesi J: The type 2 ryanodine receptor of neurosecretory PC12 cells is activated by cyclic ADP-ribose. Role of the nitric oxide/cGMP pathway. J Biol Chem 1996, 271:17739-17745.

8. Guse AH, da Silva CP, Berg I, Skapenko AL, Weber K, Heyer P, et al: Regulation of calcium signalling in $T$ lymphocytes by the second messenger cyclic ADP-ribose. Nature 1999, 398:70-73.

9. Macgregor A, Yamasaki M, Rakovic S, Sanders L, Parkesh R, Churchill GC, et al: NAADP controls cross-talk between distinct $\mathrm{Ca} 2+$ stores in the heart. J Biol Chem 2007, 282:15302-15311.

10. Cancela JM, Churchill GC, Galione A: Coordination of agonist-induced $\mathrm{Ca} 2+-$ signalling patterns by NAADP in pancreatic acinar cells. Nature 1999, 398:74-76.

11. Lee HC, Aarhus R: A derivative of NADP mobilizes calcium stores insensitive to inositol trisphosphate and cyclic ADP-ribose. J Biol Chem 1995, 270:2152-2157. 
12. Ito K, Miyashita Y, Kasai H: Micromolar and submicromolar Ca2+ spikes regulating distinct cellular functions in pancreatic acinar cells. EMBO 1997, 16:242-251.

13. Arantes LA, Aguiar CJ, Amaya MJ, Fiqueiro NC, Andrade LM, Rocha-Resende $C$, et al: Nuclear inositol 1,4,5-trisphosphate is a necessary and conserved signal for the induction of both pathological and physiological cardiomyocyte hypertrophy. J Mol Cell Cardiol 2012, 53:475-486.

14. Gomez TM, Spitzer NC: In vivo regulation of axon extension and pathfinding by growth-cone calcium transients. Nature 1999, 397:350-355.

15. Zheng JQ: Turning of nerve growth cones induced by localized increases in intracellular calcium ions. Nature 2000, 403:89-93.

16. Wiegert JS, Bading H: Activity-dependent calcium signaling and ERK-MAP kinases in neurons: a link to structural plasticity of the nucleus and gene transcription regulation. Cell Calcium 2011, 49:296-305.

17. Resende RR, Adhikari A, da Costa JL, Lorencon E, Ladeira MS, Guatimosim S, et al: Influence of spontaneous calcium events on cell-cycle progression in embryonal carcinoma and adult stem cells. Biochim Biophys Acta 1803, 2010:246-260

18. Resende RR, Adhikari A: Cholinergic receptor pathways involved in apoptosis, cell proliferation and neuronal differentiation. Cell Commun Signal 2009, 7:20.

19. Resende RR, da Costa UL, Kihara AH, Adhikari A, Lorencon E: Intracellular $\mathrm{Ca} 2+$ regulation during neuronal differentiation of murine embryonal carcinoma and mesenchymal stem cells. Stem Cells Dev 2010, 19:379-394.

20. Tonelli FM, Santos AK, Gomes DA, Da Silva SL, Gomes KN, Ladeira LO, et al: Stem cells and calcium signaling. Adv Exp Med Biol 2012, 740:891-916.

21. Rodrigues MA, Gomes DA, Nathanson MH, Leite MF: Nuclear calcium signaling: a cell within a cell. Braz J Med Biol Res 2009, 42:17-20.

22. Echevarria W, Leite MF, Guerra MT, Zipfel WR, Nathanson MH: Regulation of calcium signals in the nucleus by a nucleoplasmic reticulum. Nat Cell Biol 2003, 5:440-446.

23. Marius P, Guerra MT, Nathanson MH, Ehrlich BE, Leite MF: Calcium release from ryanodine receptors in the nucleoplasmic reticulum. Cell Calcium 2006, 39:65-73.

24. Malhas A, Goulbourne C, Vaux DJ: The nucleoplasmic reticulum: form and function. Trends Cell Biol 2011, 21:362-373.

25. Fricker M, Hollinshead M, White N, Vaux D: Interphase nuclei of many mammalian cell types contain deep, dynamic, tubular membrane-bound invaginations of the nuclear envelope. J Cell Biol 1997, 136:531-544.

26. Gomes DA, Rodrigues MA, Leite MF, Gomez MV, Varnai P, Balla T, et al: c-Met must translocate to the nucleus to initiate calcium signals. J Biol Chem 2008, 283:4344-4351.

27. Rodrigues MA, Gomes DA, Andrade VA, Leite MF, Nathanson MH: Insulin induces calcium signals in the nucleus of rat hepatocytes. Hepatology 2008, 48:1621-1631.

28. Stehno-Bittel L, Luckhoff A, Clapham DE: Calcium release from the nucleus by InsP3 receptor channels. Neuron 1995, 14:163-167.

29. Gerace L, Burke B: Functional organization of the nuclear envelope. Annu Rev Cell Biol 1988, 4:335-374.

30. Brini M, Murgia M, Pasti L, Picard D, Pozzan T, Rizzuto R: Nuclear Ca2+ concentration measured with specifically targeted recombinant aequorin. EMBO J 1993, 12:4813-4819.

31. Allbritton NL, Oancea E, Kuhn MA, Meyer T: Source of nuclear calcium signals. Proc Natl Acad Sci U S A 1994, 91:12458-12462.

32. Lin C, Hajnoczky G, Thomas AP: Propagation of cytosolic calcium waves into the nuclei of hepatocytes. Cell Calcium 1994, 16:247-258.

33. Santella L, Kyozuka K: Effects of 1-methyladenine on nuclear Ca2+ transients and meiosis resumption in starfish oocytes are mimicked by the nuclear injection of inositol 1,4,5-trisphosphate and cADP-ribose. Cell Calcium 1997, 22:11-20.

34. Hardingham GE, Chawla S, Johnson CM, Bading H: Distinct functions of nuclear and cytoplasmic calcium in the control of gene expression. Nature 1997, 385:260-265

35. Perez-Terzic C, Jaconi M, Clapham DE: Nuclear calcium and the regulation of the nuclear pore complex. Bioessays 1997, 19:787-792.

36. Lanini L, Bachs O, Carafoli E: The calcium pump of the liver nuclear membrane is identical to that of endoplasmic reticulum. $J$ Biol Chem 1992, 267:11548-11552

37. Nicotera P, McConkey DJ, Jones DP, Orrenius S: ATP stimulates Ca2+ uptake and increases the free $\mathrm{Ca} 2+$ concentration in isolated rat liver nuclei. Proc Natl Acad Sci U S A 1989, 86:453-457.
38. Xie X, Wu G, Lu ZH, Ledeen RW: Potentiation of a sodium-calcium exchanger in the nuclear envelope by nuclear GM1 ganglioside. J Neurochem 2002, 81:1185-1195

39. Gerasimenko OV, Gerasimenko JV, Tepikin AV, Petersen OH: ATP-dependent accumulation and inositol trisphosphate- or cyclic ADP-ribose-mediated release of Ca2+ from the nuclear envelope. Cell 1995, 80:439-444.

40. Adebanjo OA, Anandatheerthavarada HK, Koval AP, Moonga BS, Biswas G, Sun $L$, et al: A new function for CD38/ADP-ribosyl cyclase in nuclear Ca2+ homeostasis. Nat Cell Biol 1999, 1:409-414.

41. Gerasimenko JV, Maruyama Y, Yano K, Dolman NJ, Tepikin AV, Petersen OH, et al: NAADP mobilizes Ca2+ from a thapsigargin-sensitive store in the nuclear envelope by activating ryanodine receptors. J Cell Biol 2003, 163:271-282.

42. Wu G, Xie X, Lu ZH, Ledeen RW: Sodium-calcium exchanger complexed with GM1 ganglioside in nuclear membrane transfers calcium from nucleoplasm to endoplasmic reticulum. Proc Natl Acad Sci U S A 2009, 106:10829-10834.

43. Santella L, Carafoli E: Calcium signaling in the cell nucleus. FASEB J 1997, 11:1091-1109

44. Humbert JP, Matter N, Artault JC, Koppler P, Malviya AN: Inositol 1,4,5 trisphosphate receptor is located to the inner nuclear membrane vindicating regulation of nuclear calcium signaling by inositol 1,4,5trisphosphate. Discrete distribution of inositol phosphate receptors to inner and outer nuclear membranes. J Biol Chem 1996, 271:478-485.

45. Cardenas C, Escobar M, Garcia A, Osorio-Reich M, Hartel S, Foskett JK, et al: Visualization of inositol 1,4,5-trisphosphate receptors on the nuclear envelope outer membrane by freeze-drying and rotary shadowing for electron microscopy. J Struct Biol 2010, 171:372-381.

46. Bezin S, Charpentier G, Lee HC, Baux G, Fossier P, Cancela JM: Regulation of nuclear $\mathrm{Ca} 2+$ signaling by translocation of the $\mathrm{Ca} 2+$ messenger synthesizing enzyme ADP-ribosyl cyclase during neuronal depolarization. J Biol Chem 2008, 283:27859-27870

47. Divecha N, Rhee SG, Letcher AJ, Irvine RF: Phosphoinositide signalling enzymes in rat liver nuclei: phosphoinositidase $C$ isoform beta 1 is specifically, but not predominantly, located in the nucleus. Biochem $\mathrm{J}$ 1993, 289(Pt 3):617-620.

48. Clark EA, Brugge JS: Integrins and signal transduction pathways: the road taken. Science 1995, 268:233-239.

49. Gerasimenko O, Gerasimenko J: New aspects of nuclear calcium signalling J Cell Sci 2004, 117:3087-3094.

50. Collado-Hilly M, Shirvani H, Jaillard D, Mauger JP: Differential redistribution of $\mathrm{Ca} 2+$-handling proteins during polarisation of MDCK cells: effects on Ca2+ signalling. Cell Calcium 2010, 48:215-224.

51. Guatimosim S, Amaya MJ, Guerra MT, Aguiar CJ, Goes AM, Gomez-Viquez $\mathrm{NL}$, et al: Nuclear $\mathrm{Ca} 2+$ regulates cardiomyocyte function. Cell Calcium 2008, 44:230-242

52. Soliman EM, Rodrigues MA, Gomes DA, Sheung N, Yu J, Amaya MJ, et al: Intracellular calcium signals regulate growth of hepatic stellate cells via specific effects on cell cycle progression. Cell Calcium 2009, 45:284-292.

53. Hennager DJ, Welsh MJ, DeLisle S: Changes in either cytosolic or nucleoplasmic inositol 1,4,5-trisphosphate levels can control nuclear Ca2 + concentration. J Biol Chem 1995, 270:4959-4962

54. Malviya AN, Rogue P, Vincendon G: Stereospecific inositol 1,4,5-[32P] trisphosphate binding to isolated rat liver nuclei: evidence for inositol trisphosphate receptor-mediated calcium release from the nucleus. Proc Natl Acad Sci U S A 1990, 87:9270-9274.

55. Leite MF, Thrower EC, Echevarria W, Koulen P, Hirata K, Bennett AM, et al: Nuclear and cytosolic calcium are regulated independently. Proc Natl Acad Sci U S A 2003, 100:2975-2980.

56. Wu X, Zhang T, Bossuyt J, Li X, McKinsey TA, Dedman JR, et al: Local InsP3dependent perinuclear $\mathrm{Ca} 2+$ signaling in cardiac myocyte excitationtranscription coupling. J Clin Invest 2006, 116:675-682

57. Deisseroth K, Heist EK, Tsien RW: Translocation of calmodulin to the nucleus supports CREB phosphorylation in hippocampal neurons. Nature 1998, 392:198-202.

58. Chawla S, Hardingham GE, Quinn DR, Bading H: CBP: a signal-regulated transcriptional coactivator controlled by nuclear calcium and CaM kinase IV. Science 1998, 281:1505-1509.

59. Pusl T, Wu JJ, Zimmerman TL, Zhang L, Ehrlich BE, Berchtold MW, et al: Epidermal growth factor-mediated activation of the ETS domain transcription factor Elk-1 requires nuclear calcium. J Biol Chem 2002, 277:27517-27527. 
60. Thompson M, Andrade VA, Andrade SJ, Pusl T, Ortega JM, Goes AM, et al: Inhibition of the TEF/TEAD transcription factor activity by nuclear calcium and distinct kinase pathways. Biochem Biophys Res Commun 2003, 301:267-274.

61. Dobi A, Agoston D: Submillimolar levels of calcium regulates DNA structure at the dinucleotide repeat (TG/AC)n. Proc Natl Acad Sci U S A 1998, 95:5981-5986.

62. Rodrigues MA, Gomes DA, Leite MF, Grant W, Zhang L, Lam W, et al: Nucleoplasmic calcium is required for cell proliferation. J Biol Chem 2007, 282:17061-17068.

63. Roderick HL, Cook SJ: Ca2+ signalling checkpoints in cancer: remodelling Ca2+ for cancer cell proliferation and survival. Nat Rev Cancer 2008, 8:361-375.

64. Groigno L, Whitaker M: An anaphase calcium signal controls chromosome disjunction in early sea urchin embryos. Cell 1998, 92:193-204.

65. Taylor JT, Zeng XB, Pottle JE, Lee K, Wang AR, Yi SG, et al: Calcium signaling and T-type calcium channels in cancer cell cycling. World J Gastroenterol 2008, 14:4984-4991.

66. Trump BF, Berezesky IK: Calcium-mediated cell injury and cell death. FASEB J 1995, 9:219-228.

67. Patel R, Holt M, Philipova R, Moss S, Schulman H, Hidaka H, et al: Calcium/ calmodulin-dependent phosphorylation and activation of human $\mathrm{Cdc} 25$ C at the G2/M phase transition in HeLa cells. J Biol Chem 1999, 274:79587968.

68. Rasmussen CD, Means AR: Calmodulin is required for cell-cycle progression during G1 and mitosis. EMBO J 1989, 8:73-82.

69. Berchtold MW, Celio MR, Heizmann CW: Parvalbumin in non-muscle tissues of the rat. Quantitation and immunohistochemical localization. J Biol Chem 1984, 259:5189-5196.

70. Andressen C, Gotzos V, Berchtold MW, Pauls TL, Schwaller B, Fellay B, et al: Changes in shape and motility of cells transfected with parvalbumin cDNA. Exp Cell Res 1995, 219:420-426.

71. Guerra MT, Fonseca EA, Melo FM, Andrade VA, Aguiar CJ, Andrade LM, et al: Mitochondrial calcium regulates rat liver regeneration through the modulation of apoptosis. Hepatology 2011, 54:296-306.

72. Lagoudakis L, Garcin I, Julien B, Nahum K, Gomes DA, Combettes L, et al: Cytosolic calcium regulates liver regeneration in the rat. Hepatology 2010, 52:602-611.

73. Nicou A, Serriere V, Prigent S, Boucherie S, Combettes L, Guillon G, et al: Hypothalamic vasopressin release and hepatocyte $\mathrm{Ca} 2+$ signaling during liver regeneration: an interplay stimulating liver growth and bile flow. FASEB J 2003, 17:1901-1903.

74. Kahl CR, Means AR: Regulation of cell cycle progression by calcium/ calmodulin-dependent pathways. Endocr Rev 2003, 24:719-736.

75. Andrade V, Guerra M, Jardim C, Melo F, Silva W, Ortega JM, et al: Nucleoplasmic calcium regulates cell proliferation through legumain. J Hepatol 2011, 55:626-635.

76. Kembhavi AA, Buttle DJ, Knight CG, Barrett AJ: The two cysteine endopeptidases of legume seeds: purification and characterization by use of specific fluorometric assays. Arch Biochem Biophys 1993, 303:208-213.

77. Chen JM, Dando PM, Rawlings ND, Brown MA, Young NE, Stevens RA, et al: Cloning, isolation, and characterization of mammalian legumain, an asparaginyl endopeptidase. J Biol Chem 1997, 272:8090-8098.

78. Gawenda J, Traub F, Luck HJ, Kreipe H, von Wasielewski R: Legumain expression as a prognostic factor in breast cancer patients. Breast Cancer Res Treat 2007, 102:1-6.

79. Loak K, Li DN, Manoury B, Billson J, Morton F, Hewitt E, et al: Novel cellpermeable acyloxymethylketone inhibitors of asparaginyl endopeptidase. Biol Chem 2003, 384:1239-1246.
80. Batistatou A, Scopa CD: Pathogenesis and diagnostic significance of nuclear grooves in thyroid and other sites. Int J Surg Pathol 2009, 17:107-110

81. Andrade LM, Geraldo JM, Gonçalves OX, Leite MTT, Catarina AM, Guimarães MM, et al: Nucleoplasmic calcium buffering sensitizes human squamous cell carcinoma to anticancer therapy. J Cancer Sci Ther 2012, 4:131-139.

doi:10.1186/1478-811X-11-14

Cite this article as: Resende et al:: Nucleoplasmic calcium signaling and cell proliferation: calcium signaling in the nucleus. Cell Communication and Signaling 2013 11:14.

\section{Submit your next manuscript to BioMed Central and take full advantage of:}

- Convenient online submission

- Thorough peer review

- No space constraints or color figure charges

- Immediate publication on acceptance

- Inclusion in PubMed, CAS, Scopus and Google Scholar

- Research which is freely available for redistribution

Submit your manuscript at www.biomedcentral.com/submit
C) Biomed Central 